\section{A Simple Chromosome Doubling Technique Is Effective for Three Species of Cupressaceae}

\author{
Ryan N. Contreras ${ }^{1,2}$ \\ Department of Horticulture, Oregon State University, 4017 Agricultural and \\ Life Sciences Building, Corvallis, OR 97331-7304
}

Additional index words. polyploidy, tetraploid, oryzalin, Thuja occidentalis, Thuja plicata, Platycladus orientalis

\begin{abstract}
Platycladus orientalis (L.) Franco (syn. Thuja orientalis L.), Thuja occidentalis L., and $T$. plicata D. Don. are conifers often used in the landscape. Most of the available cultivars of these species share the character of having foliage that turns an off-color during winter as a result of photoinhibition. Tetraploids of the related japanese-cedar [Cryptomeria japonica (L. f.) D. Don.] have exhibited greener color retention than diploids during winter and a recent report described a simple technique to double its chromosomes. The technique used to double the chromosome number of $C$. japonica was applied to the three species mentioned to determine if it would be effective for inducing polyploidy and, if so, optimal duration of treatment. Seedlings were treated at the cotyledon stage for 0 (control), 10, 20, or 30 days with an aqueous solution containing $150 \mu \mathrm{M}$ oryzalin $+0.1 \%$ Tween $^{\circledR} 20$ using a standard household spray bottle that created a fine mist. No tetraploids were observed for any species in control treatments, indicating all recovered tetraploids resulted from applying oryzalin. Tetraploids were observed for all other treatments except $T$. plicata at 30 days. Efficacy ranged from $0 \%$ to $27.1 \%$ of transplanted seedlings being tetraploid. There was a quadratic relationship between duration of treatment and percent tetraploids in T. occidentalis and T. plicata and a linear relationship for $\boldsymbol{P}$. orientalis. Based on regression analysis, the optimal duration of treatment was 20.5 days for $T$. occidentalis and 13.9 days for $T$. plicata. The highest percent tetraploids recovered for $\boldsymbol{P}$. orientalis was at 30 days and it is unclear if increasing duration beyond this would continue increasing percent tetraploids recovered. Morphology was not useful in early identification of tetraploids for any species.
\end{abstract}

Platycladus orientalis, Thuja occidentalis, and T. plicata are evergreen conifers and from each species, cultivars have been selected to fill many niches in modern landscapes. Platycladus orientalis, oriental arborvitae, is native to China and Korea and is adaptable to a range of soil types and $\mathrm{pH}$ and is moderately resistant to deer browsing (Dirr, 2009). Thuja occidentalis, eastern or american arborvitae, is native to eastern North America and is tolerant of limestone soils, heat, and drought (Dirr, 2009). Thuja plicata, western red cedar or western arborvitae, is native to western North America from Alaska to northern California. Western red cedar forms a statuesque tree in the landscape, tolerates varying soil moisture, and is $\mathrm{pH}$-adaptable (Dirr, 2009). Selections of these three species include

Received for publication 27 Feb. 2012. Accepted for publication 16 Apr. 2012.

I thank Mara Friddle and Erika Wilmes for technical assistance and Ramesh Sagili, Brian Schwartz, and two anonymous reviewers for critical review of the manuscript.

Mention of a trademark, proprietary product, or vendor does not constitute and does not imply its approval to the exclusion of other products or vendors that also may be suitable.

${ }^{1}$ Assistant Professor.

${ }^{2}$ To whom reprint requests should be addressed; e-mail contrery@hort.oregonstate.edu. likely were collected from the cultivar Sieboldii, which has the synonym 'Compacta' (Krüssman, 1985). There is no evidence for a cultivar named 'Compactus'. In this report I refer to the cultivar as Compacta as a result of its prevalence in the trade and its similarity to the labeled cultivar name. With the exception of controls, $\approx 1000$ seeds of each species were sown in germination trays containing 6 Douglas fir bark [Pseudotsuga menziesii (Mirbel) Franco]:3 peat:1 pumice (v/v) and germinated under laboratory conditions in humidity chambers $(100 \%$ relative humidity) with constant light $\left(32 \mu \mathrm{mol} \cdot \mathrm{m}^{-2} \cdot \mathrm{s}^{-1}\right)$ supplied by cool-white fluorescent lamps at $20^{\circ} \mathrm{C}$. Controls of the three species were grown under the same conditions; however, only 100 seeds were sown.

Inducing polyploidy. Beginning at germination (cotyledon stage), seedlings were sprayed to runoff daily for 0 (control), 10 , 20 , or $30 \mathrm{~d}$ with an aqueous solution containing $150 \mu \mathrm{M}$ oryzalin (supplied as Surflan ${ }^{\circledR}$ AS; United Phosphorus, Trenton, NJ) $+0.1 \%$ Tween ${ }^{\circledR} 20$ (Acros Organics, Geel, Belgium) using a standard household spray bottle that created a fine mist. Each species was replicated once per treatment duration for a total of 12 trays. After each treatment the seedlings were moved to a glasshouse with day/night set temperatures of $27 / 20^{\circ} \mathrm{C}$. When seedlings were 4 to $5 \mathrm{~cm}$, they were transplanted into 32-cell trays (T.O. Plastics, Clearwater, MN) containing 1 bark mix above:1 Sunshine ${ }^{\circledR}$ SB40 patio mix (Sun Gro Horticulture, Bellevue, WA) and fertilized weekly with $100 \mathrm{ppm}$ nitrogen with Jack's Professional ${ }^{\circledR}$ 20-8.7-16.6 (J.R. Peters, Inc., Allentown, PA).

Ploidy analysis. Flow cytometry was used to screen all seedlings that survived treatments. Approximately $0.5 \mathrm{~cm}$ of leaf tissue was finely chopped in an extraction buffer (CyStain ${ }^{\circledR}$ Ultraviolet Precise P Nuclei Extraction Buffer; Partec, Münster, Germany) with a double-sided razor blade to extract nuclei. The nuclei suspension was passed through a $30-\mu \mathrm{m}$ filter (Partec), nuclei were stained with 4',6-diamidino-2-phenylindole (CyStain ${ }^{\circledR}$ ultraviolet Precise P Staining Buffer; Partec), and nuclei were analyzed using a CyFlow ${ }^{\circledR}$ Ploidy Analyzer (Partec). All samples were analyzed with an internal standard (Pisum sativum L. 'Ctirad'; $2 \mathrm{C}=8.76 \mathrm{pg}$ ) (Greilhuber et al., 2007) to correct for peak shifting and ensure correct interpretation of peak location.

Data analysis. Statistical analysis was not possible as a result of single replicates of each treatment. Percent tetraploids for each species and duration were calculated based on the number of observed tetraploids/number of surviving plants that were transplanted. Scatterplot, best fit curves, regression equations, and multiple correlation coefficients $\left(R^{2}\right)$ were prepared in Excel ${ }^{\circledR}$ (Microsoft Corporation, Redmond, WA).

Plant material. Seeds labeled as Platycladus orientalis 'Compactus', Thuja occidentalis, and Thuja plicata were received from Lawyer Nurseries, Inc. (Plains, MT). The seeds of oriental arborvitae labeled as 'Compactus'

\section{Results and Discussion}

The number of tetraploids induced in Platycladus orientalis, Thuja occidentalis, and $T$. plicata after treatment with oryzalin 
for 10,20 , or $30 \mathrm{~d}$ ranged from 0 to 107 (Table 1). No tetraploids were recovered in the control $(0 \mathrm{~d})$ treatment for any species, indicating that tetraploids observed in the study were the result of treatments and not unreduced gametes or spontaneous chromosome doubling in embryonal initials (Khoshoo, 1959). Only diploids and tetraploids were recovered in the current study. In contrast, Contreras et al. (2010) observed 9.3\% mixoploids after $30 \mathrm{~d}$ treatment of japanesecedar. It is unclear why no mixoploids were recovered in the current study.

Tetraploids were observed for all three species in each of the treatment durations except the 30-d treatment of western red cedar. There was a quadratic relationship between percent tetraploids recovered and treatment duration for T. occidentalis $\left(\mathrm{y}=-0.060 \mathrm{x}^{2}+\right.$ $\left.2.47 \mathrm{x}-0.86 ; R^{2}=0.96\right)$ and $T$. plicata $\left(-0.032 \mathrm{x}^{2}+0.89 \mathrm{x}+1.08 ; R^{2}=0.65\right)$ and a linear relationship for $P$. orientalis 'Compacta' $\left(\mathrm{y}=0.22 \mathrm{x}-0.3 ; R^{2}=0.99\right)$ (Fig. 1). Observed values of percent tetraploids for american arborvitae increased from $15.3 \%$ at $10 \mathrm{~d}$, to $27.1 \%$ at $20 \mathrm{~d}$, and declined to $18.3 \%$ at $30 \mathrm{~d}$ (Table 1). By solving for the derivative of the quadratic formula, the optimal treatment duration for american arborvitae was determined to be $20.5 \mathrm{~d}$. Observed values for percent tetraploids in oriental arborvitae increased from $1.5 \%$ at $10 \mathrm{~d}$, to $3.8 \%$ at $20 \mathrm{~d}$, and reached $6.4 \%$ at $30 \mathrm{~d}$ (Table 1). It remains to be seen if increasing treatment duration beyond $30 \mathrm{~d}$ will continue to increase the percent tetraploids recovered. Observed values for percent tetraploids of western red cedar were $10 \%$ at $10 \mathrm{~d}, 2.8 \%$ at $20 \mathrm{~d}$, and $0 \%$ at $30 \mathrm{~d}$ (Table 1). By solving for the derivative of the quadratic formula, the optimal treatment duration for inducing tetraploidy in western red cedar was $13.9 \mathrm{~d}$.

It was not possible to select tetraploids based on phenotype as can be done in pines, larix, japanese-cedar, and japanese cypress. A great deal of morphological variation among all seedlings including controls was observed, which likely contributed to the inability to select tetraploids based on phenotype. In japanese-cedar, Contreras et al. (2010) reported over 92\% accuracy when selecting for tetraploids based on plants with thick and twisted needles at an early stage of growth, which reduced the number of seedlings that were screened by flow cytometry. Tetraploids of Pinus ponderosa Douglas ex Lawson and $P$. ×attenuradiata Stockw. \& Righter polyploids exhibited thickened and shortened needles with a bluish tint but growth rate was similar to that of diploids (Hyun, 1953). Jensen and Levan (1941) described Sequoia gigantea (Lindl.) Decne. [Sequoiadendron giganteum (Lindl.) Buckholz] polyploids as having coarser and more erect branches and needles that were broader and thicker than normal. Johnsson (1975) reported altered morphology in tetraploids of Pinus sylvestris L., P. contorta Douglas ex Loud, Picea abies (L.) Karst., and Larix sibirica Ledeb. [L. russica. (Endl.) Sab. ex Trautv.]. Morphology of slash pine (Pinus elliottii

Table 1. Results of treating Platycladus orientalis 'Compacta', Thuja occidentalis, and Thuja plicata seedlings to develop tetraploids by spraying shoot tips of seedlings at the cotyledon stage with and aqueous solution of $150 \mu \mathrm{M}$ oryzalin $+0.1 \%$ Tween $^{\circledR} 20$ for $0,10,20$, or $30 \mathrm{~d}$.

\begin{tabular}{lccc}
\hline Taxon & Duration $(\mathrm{d})$ & $\begin{array}{c}\text { Seedlings } \\
\text { transplanted }(\mathrm{no} .)^{\mathrm{z}}\end{array}$ & No. $4 x\left(\% \%^{\mathrm{y}}\right)$ \\
\hline P. orientalis 'Compacta' & 0 (control) & 50 & $0(0)$ \\
P. orientalis 'Compacta' & 10 & 133 & $2(1.5)$ \\
P. orientalis 'Compacta' & 20 & 156 & $6(3.8)$ \\
P. orientalis 'Compacta' & 30 & 377 & $24(6.4)$ \\
T. occidentalis & 0 (control) & 72 & $0(0)$ \\
T. occidentalis & 10 & 400 & $61(15.3)$ \\
T. occidentalis & 20 & 395 & $107(27.1)$ \\
T. occidentalis & 30 & 240 & $44(18.3)$ \\
T. plicata & 0 (control) & 72 & $0(0)$ \\
T. plicata & 10 & 432 & $43(10.0)$ \\
T. plicata & 20 & 761 & $21(2.8)$ \\
T. plicata & 30 & 37 & $0(0)$ \\
\hline
\end{tabular}

${ }^{\mathrm{z}}$ For treatments except control, 1000 seeds were planted. Surviving seedlings were transplanted and tested. For controls, 100 seeds were planted and all surviving seedlings were transplanted and tested. yPercentage of transplanted seedlings that were tetraploid.

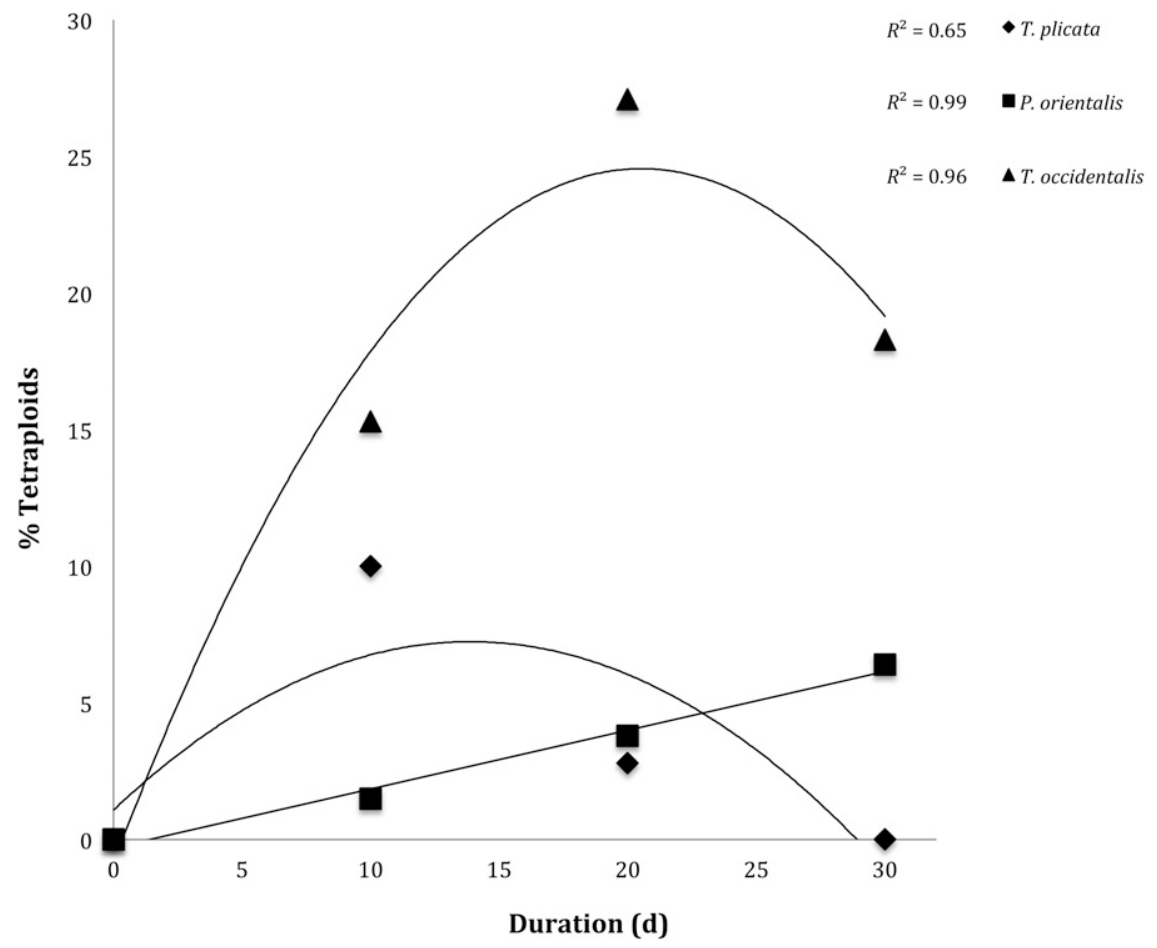

Fig. 1. Percent tetraploids resulting from treating seedlings of Thuja plicata, Thuja occidentalis, and Platycladus orientalis 'Compacta' at the cotyledon stage with a fine mist of aqueous $150 \mu \mathrm{M}$ oryzalin + $0.1 \%$ Tween ${ }^{\circledR} 20$ for $0,10,20$, or 30 d. Thuja plicata $\left(\mathrm{y}=-0.032 \mathrm{x}^{2}+0.89 \mathrm{x}+1.08\right)$ and T. occidentalis $\left(\mathrm{y}=-0.060 \mathrm{x}^{2}+2.47 \mathrm{x}-0.86\right)$ exhibited a quadratic relationship and $P$. orientalis 'Compacta' displayed a linear relationship $(y=0.22 x-0.30)$.

Engelm.) polyploids was reported to be abnormal including darker needles, shorter and thicker cotyledons and primary needles, enlarged buds, fusion of needles, and reduced growth (Mergen, 1959). Most of the species described in previous studies have needle- or awl-like leaves that perhaps display the altered character of tetraploids more effectively than in species with scalelike leaves such as arborvitae. However, Kanezawa (1951) reported tetraploids of japanese cypress [Chamecyparis obtusa (Sieb. \&
Zucc.) Endl.], a species with scale-like leaves, to have coarser branches that were more erect, broader leaves that were squatter than diploids, and leaves roughly twice as thick as diploids. An important distinction is that Kanezawa (1951) was reporting on trees at least 3 years old, whereas the current study focused on examining seedling morphology for altered phenotypes to reduce the number of seedlings to be screened using flow cytometry.

Contreras et al. (2010) previously reported on effectively using oryzalin to double the 
chromosomes of japanese-cedar using the method described here. Applying oryzalin as a mist to seedlings of three conifer species for 10,20 , or $30 \mathrm{~d}$ resulted in the recovery a total 308 tetraploids, demonstrating the efficacy of oryzalin using this treatment to induce tetraploidy among three species in two genera of Cupressaceae.

\section{Literature Cited}

Contreras, R.N., J.M. Ruter, and B.M. Schwartz. 2010. Oryzalin-induced tetraploidy in Cryptomeria japonica (Cupressaceae). HortScience 45:316-319.
Dirr, M.A. 2009. Manual of woody landscape plants: Their identification, ornamental characteristics, culture, propagation and uses. 6th Ed. Stipes, Champaign, IL.

Greilhuber, J., E.M. Temsch, and J.M. Loureiro. 2007. Nuclear DNA content measurement, p. 67-101. In: Dolezěl, J. Greilhuber, and J. Suda (eds.). Flow cytometery with plant cells: Analysis of genes, chromosomes and genomes. Wiley-VCH, Weinheim, Germany.

Hyun, S.K. 1953. Induction of polyploidy in pines by means of colchicine treatment. Z. Forstgenetik 3:25-33.

Jensen, H. and A. Levan. 1941. Colchicine-induced tetraploidy in Sequoia gigantea. Hereditas 27:220-224.
Johnsson, H. 1975. Observations on induced polyploidy in some conifers. Silvae Genet. 24:62-68.

Kanezawa, R. 1951. Induced tetraploidy in Japanese cypress (Chamaecyparis obtusa Endl.). Bul. Tokyo Univ. For. 39:21-30.

Khoshoo, T.N. 1959. Polyploidy in gymnosperms. Evolution 13:24-39.

Krüssman, G. 1985. Manual of cultivated conifers. 2nd Ed. Timber Press, Portland, OR.

Mergen, F. 1959. Colchicine-induced polyploidy in pines. J. For. 57:180-190.

Niwa, Y. and Y. Sasaki. 2003. Plant self-defense mechanisms against oxidative injury and protection of the forest by planting trees of triploids and tetraploids. Ecotoxicol. Environ. Saf. 55:70-81. 